


\title{
FORAGE PRODUCTIVITY OF ARBILA (Phaseolus lunatus) AT VARIOUS LEVELS OF RHIZOBIUM INOCULANTS AND HARVESTING TIMES
}

\author{
B. B. Koten ${ }^{1,2}$, R. D. Soetrisno ${ }^{1}$, N. Ngadiyono ${ }^{1}$ and B. Soewignyo ${ }^{1}$ \\ ${ }^{1}$ Faculty of Animal Science, Gadjah Mada University, \\ Jl. Fauna No. 3, Bulaksumur Yogyakarta - Indonesia \\ ${ }^{2}$ Permanent Address: Department of Animal Husbandry, State Agriculture Polytechnic of Kupang, \\ Jl. Adisucipto, Kupang Penfui, NTT - Indonesia \\ Corresponding E-mail : bernadete_koten@yahoo.com
}

Received October 23, 2012; Accepted November 28, 2012

\begin{abstract}
ABSTRAK
Penelitian bertujuan untuk mengevaluasi produktivitas hijauan arbila (Phaseolus lunatus) sebagai pakan ruminansia pada berbagai level inokulum rizobium dan umur panen, telah dilaksanakan selama 5 bulan, dirancang dengan rancangan acak lengkap pola faktorial dengan 2 faktor perlakuan. Faktor pertama yaitu level inokulum (I): I1 (tanpa inokulum), I2 (5 g/kg benih), I3 (10 g/kg benih), dan I4 (15 $\mathrm{g} / \mathrm{kg}$ benih). Faktor kedua adalah umur panen (U) yaitu U1 (dipanen pada umur 60 hari), U2 (dipanen pada umur 80 hari), U3 (dipanen pada umur 100 hari), yang diulang sebanyak 4 kali. Variabel yang diamati adalah serapan nitrogen $(\mathrm{N})$, produksi bahan kering $(\mathrm{BK})$, produksi bahan organik $(\mathrm{BO})$, kadar BO, kadar protein kasar (PK), kadar serat kasar (SK), kadar bahan ekstrak tanpa nitrogen (BETN), kadar ekstrak eter (EE), dan kadar abu hijauan arbila. Hasil penelitian menunjukkan bahwa dosis inokulum rizobium $15 \mathrm{~g} / \mathrm{kg}$ (I4) benih menghasilkan persentase bintil akar efektif tertinggi $(98,72 \%$ ) dan kombinasinya dengan umur panen 100 hari (I4U3) mampu menghasilkan produktivitas tertinggi yaitu dapat mengabsorbsi $\mathrm{N}$ sebesar 688,10 g/polybag dengan produksi BK 273,81 g/polybag, produksi BO 263,96 g/polybag, serta kandungan nutrien sebagai berikut: 91,14 \% BO, 33,52\% SK, 34,76\% BETN, $5,75 \%$ EE, 09,37\% abu, dan 16,16\% PK. Dari hasil penelitian disimpulkan bahwa produktivitas hijauan arbila sebagai pakan ruminansia tertinggi terdapat pada kombinasi perlakuan antara dosis inokulum 15 $\mathrm{g} / \mathrm{kg}$ benih dengan umur panen 100 hari.
\end{abstract}

Kata kunci : Phaseolus lunatus, umur panen, Inokulum rizobium, produktivitas, hijauan

\begin{abstract}
The study was conducted to evaluate forage productivity of arbila (Phaseolus lunatus) as the ruminant feed at various levels of rhizobium inoculants and harvesting times, was designed following completely randomized design of factorial pattern with two factors. The first factor was the level of inoculums (I) i.e. I1 (without inoculum), I2 (5 g/kg seed), I3 (10 g/kg seed), and I4 (15 g/kg seed). The second factor was harvesting time (U) i.e. U1 (60 days), U2 (80 days), U3 (100 days) with 4 replications. The variables were $\mathrm{N}$ uptake, production of dry matter (DM) and organic matter $(\mathrm{OM})$, and percentage of OM, crude protein (CP), crude fiber (CF), nitrogen free extract (NFE), extract ether (EE) and ash of arbila forage (based on DM). The results showed that inoculant treatment at the rate of 15 $\mathrm{g} / \mathrm{kg}$ seed produced the highest percentage of effective nodules $(98.72 \%)$, and in combination with harvesting age at 100 days each polybag of plant was able to absorb the higest amount of $\mathrm{N}(688.10 \mathrm{~g})$ with production of DM $273.81 \mathrm{~g}$, OM production $263.96 \mathrm{~g}$ and nutrients content based on DM of about 91.14\% OM, 33.52\% CF, 34.76\%, 5.75\% EE, 09.37\% ash, and 16.16\% CP. From the study, it can be concluded that arbila plants inoculated specific rhizobium Phaseolus vulgaris at the rate of $15 \mathrm{~g} / \mathrm{kg}$ seed and harvested at 100 days yielded the best forage as feed.
\end{abstract}

Keywords: Phaseolus lunatus, harvesting time, Rhizobium inoculant, productivity, forage

\section{INTRODUCTION}

The quality and quantity of forage as the feed is highly determining productivity of ruminant animal. This condition is still an obstacle in East Nusa Tenggara, mainly due to the 
longer dry season (8 - 9 months) than the rainy season (3 - 4 months), and limited ability of grass foliage as a single feed for meeting the full nutrients needed by the livestock. So needed to add the legume to complementary nutrient elements needed by ruminant. Arbila (Phaseolus lunatus) is one of the native legumes, which normally grown in the field of natural grazing in East Nusa Tenggara. This legume is a vine with a wide adaptability to its environment, grows and produces well in the lowlands to the highlands, resistant to drought, can grow in almost any type of soil, and tolerant of acidic soils. The analysis results conducted in the Pasture and Forage Laboratory of Animal Science Faculty of Gadjah Mada University (2010) showed that the vegetative part of arbila legume contained of (bassed on dry matter (DM): $13.48 \%$ ash, $21.21 \%$ crude protein (CP), $3.79 \%$ ether extract (EE), and $24.21 \%$ crude fiber (CF). Therefore, arbila is potential legume plant that can be developed as source of high quality of feed, especially in dry season.

Root nodules of arbila are the place of rhizobium bacterium life that can afford to tie up air $\mathrm{N}$. The $\mathrm{N}$ fixation occurs symbiotically in root nodules of the plant where the $\mathrm{N}$ gas of the air is reduced to ammonia (Ferguson et al., 2010). Ammonia $\left(\mathrm{NH}_{3}\right)$ is transported out of bacteroids before it can be metabolized further and used by the host plant. Nitrogen is absorbed by plants in the form of $\mathrm{NO}_{3}$ (nitrate) and ammonium $\left(\mathrm{NH}_{4}\right)$. The ability of tying air $\mathrm{N}$ is determined by the rhizobium effectiveness. Ineffective bacteria are parasitic for plants. Inoculation with culture of selected strain is hopefully able to substitute for less effective natural rhizobium. Seed inoculation with the appropriate rhizobium strain is necessary to ensure the establishment of effective root nodules (Fuskhah, 2011). Abdullah (2004) reported that rhizobium inoculation improved significantly herbage- $\mathrm{N}$ uptake, protein content and legume crop production. Koten et al. (2005) also reported that the addition of rhizobium inoculum on cowpea increased DM biomass from 1.63 to 2.48 ton/ha, CP content from $16.37 \%$ to $17.04 \%$, and decreased CF content from $34.18 \%$ to $32.21 \%$. Nevertheless, plant responses vary depending on the soil conditions and the effectiveness of the native rhizobium population. Too little amount of inoculants causes the rhizobium unable to compete with the original rhizobium in the soil, which limits the amount of air $\mathrm{N}$ tethered. However, excessive of inoculant will impact on too many rhizobium, which can parasitic to plant. This condition would affect on forage productivity of arbila. Therefore the determination of appropriate levels of inoculant is needed to produce the good arbila forage as ruminant feed.

The maturity level of the plants is an important factor affecting production, nutritive value, and digestibility of foliage (Koten et al., 2005). During its vegetative period the plant will produce more of assimilation results than it uses. The excess of assimilation results will be stored in the vegetative part as backup compounds. The backup compounds are mostly composed of carbohydrates but often also contain a fair amount of lipid and protein. With increasing age of the plant, the DM production and total non-structural carbohydrates in grass crops will also increased (Budiman et al., 2011). On the other hand, the contents of protein, minerals and soluble carbohydrate of the plant will be reduced with increasing age of the plant, while the lignin and crude fiber contents increased (Budiman, 2012). Determining the appropriate harvesting age is necessary to ensure the amount of crop production with sufficient nutritive value for animal feed. Information of arbila legume (Phaseolus lunatus) forage productivity as ruminant feed as a result of different rates of inoculant and harvesting times application have not yet been done, therefore, this study was conducted.

\section{MATERIALS AND METHODS}

\section{Materials}

This study was conducted in the greenhouse of Pasture and Forage Laboratory of Animal Science Faculty of Gadjah Mada University for 5 months from November 2011 to March 2012. Materials used were arbila legume seeds of local varieties of Kupang - NTT, rhizobium inoculant (Legin Phaseolus vulgaris), SP $36\left(36 \% \mathrm{P}_{2} \mathrm{O}_{5}\right)$, and $\mathrm{KCl}\left(60 \% \mathrm{~K}_{2} \mathrm{O}\right)$ and urea $(45 \% \mathrm{~N})$ fertilizers, polybag $18 \times 23 \mathrm{~cm}$ with diameter of $22 \mathrm{~cm}$, plastic bags and paper bags. The equipment used was a digital scale of $200 \mathrm{~g}$ capacity with its smallest scales $0.0001 \mathrm{~g}$ to weigh inoculants and fertilizers, and scale of $5 \mathrm{~kg}$ capacity with a sensitivity $0.5 \mathrm{~g}$ to weigh soil and foliage, a drying oven, a set of Kjedahl analysis tools to measure of crude protein, a crude fiber test tool, extract ether tool, and furnace. 


\section{Methods}

This study consisted of four levels of inoculant dose (I) and tree levels of harvesting time $(\mathrm{U})$. The dose of inoculant consisted of no inoculums, $5 \mathrm{~g} / \mathrm{kg}$ seed, $10 \mathrm{~g} / \mathrm{kg}$ seed, and $15 \mathrm{~g} / \mathrm{kg}$ seed, which referred as I1, I2, I3, and I4, respectively. The harvesting time consisted of harvested at 60-d, 80-d, and 100-d of growth, which referred as U1, U2, dan U3, respectively.

Soil preparation comprises destruction of soil, then put the prepared soil into polybags as much as $10 \mathrm{~kg} /$ polybag. Polybags were placed at distances of $0.5 \times 0.5 \mathrm{~m}$. The treatment determination of the polybags was performed randomly based on completely randomized design patterns. The seeds were wetted with water and then added legin according to the treatment doses. Seeds that were mixed with inoculums then were dibbled at the rate of 4 seeds/hole. Fertilizer SP 36 $\left(36 \% \mathrm{P}_{2} \mathrm{O}_{5}\right)$ at a dose of $75 \mathrm{~kg} / \mathrm{ha}$ was given together with planting, $\mathrm{KCl}\left(60 \% \mathrm{~K}_{2} \mathrm{O}\right)$ as much as $75 \mathrm{~kg} / \mathrm{ha}$ was given 2 times, and urea fertilizer at the rate of $25 \mathrm{~kg} / \mathrm{ha}$ was applied 10 days after seedling to stimulate early growth. Thinning out of the plants was done with only leaving 2 best plants. Watering plants was done every day. Weeding was done manually if there was a weed and while pest overcome by spraying insecticides. Harvesting by cutting the stalks $\pm 5 \mathrm{~cm}$ above the ground was done according to the treatment, and the foliage production was measured. Samples of foliage were put into paper bag and then were dried in the oven at temperature of $55^{\circ} \mathrm{C}$ until reached a constant weight. The samples were then weighed and milled with the hole diameters of mill sieve $1 \mathrm{~mm}$. Samples were analysed of the DM, CP, CF, EE, NFE, and ash contents were done according to AOAC (2005).

\section{Observed Variables}

The observed variables were $\mathrm{N}$ uptake of arbila $(\mathrm{g} /$ polybag), DM and $\mathrm{OM}$ production of arbila (g/polybag), contents of OM, CP (Kjedahl method), CF, EE, NFE, and ash in \% DM.

\section{Data Analysis}

Variance analysis of obtained data was carried out according to the completely randomized design of factorial pattern 4 x 3 , followed by Duncan test (Duncan's new multiple range test / DMRT) as directed by Gomez and Gomez (1984).

\section{RESULTS AND DISCUSSION}

\section{Nitrogen Absorbed by Arbila}

Analysis of variance results showed that nitrogen absorbed by plants was highly significant affected $(\mathrm{P}<0.01)$ by the dose of inoculant, harvesting time and interaction between dose of inoculant with harvesting time. Bassed on the DMRT test, it was found that the highest $(\mathrm{P} \leq 0.05)$ $\mathrm{N}$ uptake was recorded when arbila treated with inoculant at the rate of $15 \mathrm{~g} / \mathrm{kg}$ of seed and harvested at 100-d of age (Table 1).

It appears that $\mathrm{N}$ was increased absorbed by arbila along with increasing doses of inoculant. This occured because the more inoculum was added, the higher activity of bacteria rhizobium will be. The higher activity of $\mathrm{N}$ fixation by rhizobium will cause more and more $\mathrm{N}$ that can be available absorbed by arbila. The average of the effective root nodule percentage due to different doses of inoculant were: $11.71 \%$, $74.30 \%, 92.29 \%$, and $98.72 \%$ at $0,5,10$, and 15 $\mathrm{g} / \mathrm{kg}$ of seed, respectively. Nitrogen uptake was increased with increasing age of the plant. Based on the observations, arbila started to form root nodules at 20 days of age. Nodule formation continues to grow rapidly until arbila crop harvested at 100 days. The high activity of mooring $\mathrm{N}$ will cause more and more $\mathrm{N}$ available. Furthermore, the high activity of the plants in photosynthesis, it will be caused high $\mathrm{N}$ uptake by plants.

Soil analysis results showed that $\mathrm{N}$ soil before planting was $339 \mathrm{ppm}$, and after planting arbila without inoculum was $404.5 \mathrm{ppm}$. Soil N was increased with increasing doses of inoculum (15 g/kg of seed) and harvesting age (100-d) that was $614.25 \mathrm{ppm}$. The high $\mathrm{N}$ fixed by rhizobium in the nodules of arbila root resulted in high of crop production, and this condition was shown by the DM and OM production of arbila treated with $15 \mathrm{~g}$ inoculant $/ \mathrm{kg}$ of seed and harvesting at $100-\mathrm{d}$ of age (Tabel 1). The results was consistent with finding research conducted by Abdullah (2004), he found that the addition of rhizobium inoculant on Arachis pintoi was able to increase the uptake of $\mathrm{N}$ and even affected the uptake of P. Fuskhah $e t$ al. (2007) explained that rhizobium-legume associations led to the formation of effective nodules that can fix the free nitrogen from the air, so that it can supply the $\mathrm{N}$ needed of the plant. Nitrogen fixation results are used by the legume host plants to live and produce biomass. The mean nitrogen absorbed by arbila in this study was 
Table 1. The Average of N Uptake, DM and OM Production of Arbila Foliage as a Result of Interaction between Inoculum Level and Harvesting Time (g/polybag)

\begin{tabular}{cccc}
\hline Treatment & N uptake & DM production & OM production \\
\hline U1 (60 days harvested) & $64.20^{\mathrm{h}}$ & $22.57^{\mathrm{g}}$ & $23.06^{\mathrm{f}}$ \\
I1 & $74.70^{\mathrm{h}}$ & $25.76^{\mathrm{g}}$ & $25.74^{\mathrm{ef}}$ \\
I2 & $86.56^{\mathrm{h}}$ & $29.23^{\mathrm{g}}$ & $28.94^{\mathrm{ef}}$ \\
I3 & $94.82^{\mathrm{g}}$ & $31.20^{\mathrm{g}}$ & $30.98^{\mathrm{e}}$ \\
I4 & & & \\
U2 (80 days harvested) & $125.35^{\mathrm{fg}}$ & $46.57^{\mathrm{fg}}$ & $44.92^{\mathrm{e}}$ \\
I1 & $166.21^{\mathrm{ef}}$ & $58.12^{\mathrm{ef}}$ & $58.48^{\mathrm{d}}$ \\
I2 & $192.94^{\mathrm{de}}$ & $66.40^{\mathrm{de}}$ & $63.56^{\mathrm{d}}$ \\
I3 & $222.59^{\mathrm{d}}$ & $75.76^{\mathrm{d}}$ & $71.74^{\mathrm{d}}$ \\
I4 & & & $100.04^{\mathrm{d}}$ \\
U3 (100 days harvested) & $253.79^{\mathrm{cd}}$ & $103.2^{\mathrm{c}}$ & $115.09^{\mathrm{c}}$ \\
I1 & $290.42^{\mathrm{c}}$ & $117.93^{\mathrm{b}}$ & $151.59^{\mathrm{b}}$ \\
I2 & $387.59^{\mathrm{b}}$ & $157.33^{\mathrm{b}}$ & $263.96^{\mathrm{a}}$ \\
I3 & $688.10^{\mathrm{a}}$ & $273.8^{\mathrm{a}}$ & 7.26 \\
I4 & 22.65 & 7.58 & \\
\hline Sd & & & \\
\hline
\end{tabular}

Different superscripts in the same column indicate significantly different $(\mathrm{P}<0.05) ; \mathrm{Sd}=$ standard of deviation, I1 (0 g inoculant $/ \mathrm{kg}$ of seed), I2 ( $5 \mathrm{~g}$ inoculant $/ \mathrm{kg}$ of seed), I3 (10 g inoculant $/ \mathrm{kg}$ of seed), and I4 (15 $\mathrm{g}$ inoculant $/ \mathrm{kg}$ of seed).

$220.61 \mathrm{~g} /$ polybag. This amount was greater than the $\mathrm{N}$ uptake by Arachis pintoi ranged from 315$533 \mathrm{mg} /$ pot (Abdullah, 2004), and $\mathrm{N}$ uptake by Centrosema pubescens were $2.14-2.49 \mathrm{~g} / \mathrm{m}^{2}$ reported by Pudjiarti (2004).

\section{DM and OM Production}

Analysis of variance results showed that the DM dan OM production of arbila forage very significantly $(\mathrm{P}<0.01)$ increased with increasing the inoculant dose, harvesting time and the interaction between dose of inoculant and harvesting time.

The high DM and OM production of arbila due to increasing dose of inoculum, can be understood because the more appropriate inoculum was added, the higher the activity of nitrogen fixing bacteria in the nodules will be. This condition leads to the increasing number of nitrogen used for growth and crop production of arbila. Increased of growth and crop production resulted in the increased of $\mathrm{DM}$ and $\mathrm{OM}$ productions (Table 1). Widawati (2010) reported her finding that microbes found in marginal land obviously able to synthesize auxin, cytokinins, vitamins, and gibberellins. This was consistent with the results reported by Evensen and Blevins (1981) that Phaseolus lunatus in which was inoculated with appropriate rhizobium yielded gibberellin responsible for the differences in growth compared to non inoculated plants. These components improve germination, stimulates the development of root systems, and increase the capacity of the roots to absorb nutrients and water needed for the development of plant organs. Increased number of rhizobium would increased the decomposition of organic matter that came from decaying roots and leaves of deciduous plants. The high organic matter, besides a source of nutrients for the formation of organic plants, also would improve soil quality, which will further enhance the absorption of water and nutrients needed to form materials of production. In the other hand, with the lengther of time to 
harvesting, the organic materials produced will also accumulated in plant tissues. The respective mean of DM and OM production of arbila forage in this study was $83.99 \mathrm{~g} /$ polybag and 81.51 g/polybag. This amount was greater than the dry weight of peanut plants (3.19 to $10.29 \mathrm{~g} / \mathrm{plant}$ ) at the age of 11 weeks after planting (Dimu-Heo, 2012), and comparable with the production of Stylosanthes guianensis (80.63 to $88.53 \mathrm{~g} / \mathrm{plant}$, calculated from 10079.35 to $11066.08 \mathrm{~kg} / \mathrm{ha}$ at planting distance of $40 \times 20 \mathrm{~cm}$ ) recorded by Hutasoit (2010), but higher than DM production of Centrosema pubescens (50.3 - $115.1 \mathrm{~kg} / \mathrm{ha})$ as reported by Lukiwati (2007).

\section{Nutritive Value Content of Arbila Foliage}

Analysis of variance results showed that the CP contents of arbila foliage were highly significant $(\mathrm{P} \leq 0.01)$ affected by inoculum dose, harvesting time, and the combination of inoculum dose and harvesting time. Table 2 shows that the CP contents of arbila plants increased with the addition of inoculum dose. This condition suggests that rhizobium inoculation was very effective in tying up air nitrogen. This condition was also supported by the high percentage $(98.72 \%)$ of effective root nodules when applied the a rate of $15 \mathrm{~g} / \mathrm{kg}$ of seed. This was in accordance with Purwaningsih (2011) opinion that added inoculant at Arachis hypogea plant increased $\mathrm{N}$ uptake and total of nitrogen in its plant tissue. However the crude protein contents decreased with increasing age of plant. In the combined treatments, either treatment I3 (10 g/ kg) or I4 $(15 \mathrm{~g} / \mathrm{kg})$ combined with U1 (60-d of harvesting age) were able to produce high and statiscally the same CP content, and both were significantly $(\mathrm{P}<0.05)$ higher than the $\mathrm{CP}$ content of the other treatment combinations. There were significant differents in CP content yielded by treatment combination beetwen levels of inoculum and age of harvesting. The $\mathrm{CP}$ content increased $(\mathrm{P}<0.05)$ with increasing levels of inoculum both in 80 (U2) and 100-d of harvesting age (U3). Mean while, the CP content decreased $(\mathrm{P}<0.05)$ as the harvesting age increased to $100-\mathrm{d}$,

Tabel 2. The Average of Nutritive Value of Arbila Foliage as a Result of Interaction between Inoculum Level and Harvesting Time (\% DM)

\begin{tabular}{ccccccc}
\hline Treatment & OM & CP & CF & NFE & EE & Ash \\
\hline U1 (60 days harvested) & & & & & & \\
I1 & $89.64^{\mathrm{e}}$ & $20.26^{\mathrm{b}}$ & $26.86^{\mathrm{f}}$ & $34.18^{\mathrm{c}}$ & $06.89^{\mathrm{a}}$ & $11.80^{\mathrm{c}}$ \\
I2 & $88.73^{\mathrm{f}}$ & $20.34^{\mathrm{b}}$ & $29.02^{\mathrm{e}}$ & $31.68^{\mathrm{d}}$ & $06.27^{\mathrm{a}}$ & $12.69^{\mathrm{a}}$ \\
I3 & $89.04^{\mathrm{f}}$ & $20.59^{\mathrm{a}}$ & $28.92^{\mathrm{e}}$ & $31.5^{\mathrm{e}}$ & $06.80^{\mathrm{a}}$ & $12.19^{\mathrm{ab}}$ \\
I4 & $89.36^{\mathrm{e}}$ & $21.11^{\mathrm{a}}$ & $29.37^{\mathrm{d}}$ & $32.69^{\mathrm{d}}$ & $05.00^{\mathrm{c}}$ & $11.83^{\mathrm{bc}}$ \\
U2 (80 days harvested) & & & & & & \\
I1 & $90.32^{\mathrm{c}}$ & $18.00^{\mathrm{d}}$ & $29.10^{\mathrm{e}}$ & $37.60^{\mathrm{a}}$ & $04.96^{\mathrm{c}}$ & $10.34^{\mathrm{d}}$ \\
I2 & $90.92^{\mathrm{b}}$ & $19.79^{\mathrm{c}}$ & $31.41^{\mathrm{b}}$ & $32.37^{\mathrm{d}}$ & $06.37^{\mathrm{a}}$ & $10.05^{\mathrm{e}}$ \\
I3 & $90.64^{\mathrm{bc}}$ & $19.18^{\mathrm{c}}$ & $30.11^{\mathrm{cd}}$ & $35.04^{\mathrm{b}}$ & $05.79^{\mathrm{b}}$ & $09.88^{\mathrm{f}}$ \\
I4 & $90.15^{\mathrm{d}}$ & $19.29^{\mathrm{c}}$ & $30.47^{\mathrm{c}}$ & $34.20^{\mathrm{c}}$ & $05.69^{\mathrm{b}}$ & $10.35^{\mathrm{d}}$ \\
U3 (100 days harvested) & & & & & & \\
I1 & $90.51^{\mathrm{b}}$ & $16.45^{\mathrm{e}}$ & $32.11^{\mathrm{b}}$ & $35.26^{\mathrm{b}}$ & $06.02^{\mathrm{b}}$ & $10.16^{\mathrm{d}}$ \\
I2 & $91.37^{\mathrm{a}}$ & $16.44^{\mathrm{f}}$ & $32.92^{\mathrm{a}}$ & $35.54^{\mathrm{b}}$ & $05.89^{\mathrm{b}}$ & $09.21^{\mathrm{g}}$ \\
I3 & $91.17^{\mathrm{a}}$ & $16.26^{\mathrm{f}}$ & $33.28^{\mathrm{a}}$ & $34.82^{\mathrm{b}}$ & $06.32^{\mathrm{a}}$ & $09.33^{\mathrm{g}}$ \\
I4 & $91.14^{\mathrm{a}}$ & $16.60^{\mathrm{e}}$ & $33.52^{\mathrm{a}}$ & $34.76^{\mathrm{b}}$ & $05.75^{\mathrm{b}}$ & $09.37^{\mathrm{f}}$ \\
\hline Sd & 0.19 & 0.26 & $0.32^{\mathrm{a}}$ & 0.48 & 0.29 & 0.20 \\
\hline
\end{tabular}

Different Superscripts in the same column indicate there are significant differences $(\mathrm{P} \leq 0.05)$, and $\mathrm{Sd}=$ standard of deviation, I1 ( $0 \mathrm{~g}$ inoculant $/ \mathrm{kg}$ of seed), I2 ( $5 \mathrm{~g}$ inoculant $/ \mathrm{kg}$ of seed), I3 (10 g inoculant $/ \mathrm{kg}$ of seed), and I4 (15 g inoculant $/ \mathrm{kg}$ of seed). 
and showed that lowest $\mathrm{CP}$ content was obtained in $\mathrm{I} 1 \mathrm{x}$ U3. The low CP content in combination with $\mathrm{U} 3$ can be attributed to the movement of $\mathrm{CP}$ from the leaves for the formation of generative parts of the plant. This was in accordance with Barnes et al. (2007), he found that CP content at forage decreased with increasing of harvesting time. This was chiefly due to a significant loss of leaves from the lower internodes of the stem material and a drop in leaf-to-stem ratio. Koten et al. (2005) reported that CP content at cowpea foliage decreased with increasing of harvesting time i.e $17.29 \%$ in 60 -d to $16.11 \%$ in 70 -d.

The average CP content of arbila foliage in this study was $18.69 \%$. This amount was within the range of CP content of alfalfa plants (18.26 to $21.83 \%$ ) as reported by Parman (2007), but lower than CP content of Phaseolus lunatus forage (19.4\%) as reported by Ajayi et al. (2009) and CP content of Centrosema pubescens forage as recorded by Tarigan and Ginting (2005).

Analysis of variance showed that the $\mathrm{CF}$ contents of arbila plants were greatly affected $(\mathrm{P}<0.01)$ by factors of inoculant dose, harvesting time and combination of inoculant dose and harvesting time. The CF contents were increased $(\mathrm{P}<0.05)$ with increasing levels inoculant. However there were different variation among the treatments. Crude fiber $(\mathrm{CF})$ contents increased $(\mathrm{P}<0.05)$ with increasing the harvesting time (Table 2), the highest CF contents were found in treatments $15 \mathrm{~g} / \mathrm{kg}$ of seed with $100-\mathrm{d}$ harvested and the lowest was in treatment no inoculant with 60-d harvested. When entering the generative period, the non-structural carbohydrates of the plant will be used to form the pod resulted in increasing, which causing structural carbohydrates level increas. Budiman (2012) suggested that structural carbohydrate increased with increasing of age plant. Increasing age of harvesting and with an addition of inoculums, yielded increasing accumulation of biomass including CF content in the plant tissue. The CF was the main carbohydrate compound of biomass. When the plants are growing and developing, they form the primary cell wall and when their growth is completed, they form the secondary cell wall. The cell wall is composed of cellulose, hemicellulose, pectin and lignin. Thus, the higher the plant age, the higher the $\mathrm{CF}$ content. The average $\mathrm{CF}$ content of arbila foliage in this study was $30.59 \%$. This CF content was apparently lower than the CF content of calopo (34.00\%) as reported by Fuskhah (2011), and CF content of
Medicago sativa inoculated $(32.51-37.76 \%)$ as recorded by Widyati-Slamet et al. (2009), but higher than the $\mathrm{CF}$ content of Stylosanthes guianensis $(28.5 \%)$ as reported by Hutasoit (2010).

Ether extract (EE) content of arbila were also depended $(\mathrm{P} \leq 0.05)$ on inoculum dose, harvesting time, and its combination. Arbila treated with inoculant at the rate of 0,5 , and $10 \mathrm{~g}$ harvested at 60-d, $5 \mathrm{~g}$ harvested at 80-d and $10 \mathrm{~g}$ harvested at 100-d of age recorded statistically the same EE content, and were higher than the other treatments (Table 2). The changes of EE contents was caused by the reduced of lipids for carbohidrates production with increasing of plant age. According to Heldt and Piechulla (2011), lipids storage was mobilized for the production of carbohidrates. In this study were found that the EE content was decreased $(\mathrm{P}<0.05)$ about $28.0 \%$ when harvesting was done at $80-\mathrm{d}$, but then increased $(\mathrm{P}<0.05)$ again of about $21.4 \%$ when harvesting was performed at 100-d of age. The average of EE contents arbila foliage in this study was $5.98 \%$. This content was higher than the average of EE content of cowpea foliage (3.69\%) as reported by Koten et al. (2005), and EE content of Phaseolus lunatus forage $(1.5 \%)$ as reported by Ajayi et al. (2009).

Table 2 showed that the highest NFE content was recorded in no inoculant with $80-\mathrm{d}$ harvested treatment, and the lowest was in $10 \mathrm{~g} / \mathrm{kg}$ of seed with 60-d harvested. At the longer time of harvesting, there will be more nitrogen translocated into the generative parts of the plant. Therefore, the NFE got higher than in the younger plant. The average of NFE contents arbila foliage in this study was $34.14 \%$. This NFE content was lower than the average of NFE contents of stylo foliage (37.66\%) as recorded by Amakali (2012), but higher than NFE content of lima beans forage (11.8\%) as reported by Ajayi et al. (2009).

Analysis of variace showed that the ash contents of arbila foliage were highly significant $(\mathrm{P}<0.01)$ affected by harvesting time and its combination treatment between inoculant dose and harvesting time, but the inoculant dose factor did not affected the ash contents $(P>0.05)$. In the harvesting time factor, ash contents decreased in compliance with the increasing harvesting time. In the combinations treatment, inoculant 5, and 10 $\mathrm{g} / \mathrm{kg}$ of seed with $60-\mathrm{d}$ harvested have ash content more high than the others. The lowest ash contents were observed in the inoculant 5 and 10 $\mathrm{g} / \mathrm{kg}$ of seed with 100-d harvested treatments. 
The longer the harvesting age, the more minerals utilized by the plants to support the growth and production processes. This condition resulted in the decreased of inorganic substance contents in the plant tissues. The average of ash contents in this study was $10.60 \%$. This ash content was higher than the average of ash contents of stylo foliage $(9.29 \%)$ as reported by Amakali (2012), and was in the ranged of alfalfa foliage ash content (9.51 to $15.76 \%$ ) as stated by Sirait et al. (2011), and ash contents of cowpea foliage ( 7.50 to $10.96 \%$ ) as reported by Koten et al. (2005).

\section{CONCLUSION}

It can be concluded that the forage productivity of arbila legume apparently increased with increasing doses of rhizobium inoculums and increasing harvesting time. The combination between rhizobium inoculum dose of $15 \mathrm{~g} / \mathrm{kg}$ seed and 100-d harvested yielded the best arbila foliage as ruminant feed.

\section{ACKNOWLEDGMENT}

Thanks to the post-graduate scholarship program (BPPS) by Directorate General of Higher Eduation that has funded this research.

\section{REFERENCES}

Abdullah, L. 2004. Efektivitas inokulasi rhizobium terhadap perbaikan serapan $\mathrm{N}$ dan $\mathrm{P}$ serta kandungan protein legum Arachis pintoi pada tingkat keasaman tanah yang berbeda. Jurnal Ilmu Ternak. 4 (2):53 - 56.

Ajayi, F. T., S. R. Akande, A. A. Adegbite, and B. Idowu. 2009. Assessment of seven underutilized grain legume foliages as feed resources for ruminants. Livestock Research for Rural Development. 21 (9): 149-156.

Amakali, J. L. 2012. Effect of Residual Rock Phosphate and Biofertilizers (Rhizobium and Biophosphate) and their Combinations on the Productivity of Stylosanthes guianensis CIAT 184. Thesis. Post Graduate Program, Faculty of Animal Science, Gadjah Mada University, Yogyakarta.

AOAC. 2005. Official Methods of Analysis of the Association of Official Analytical Chemists. Published by the Association of Official Analytical Chemists. Maryland.

Barnes R.F., C. J. Nelson., K. J. Moore and M.
Collins. 2007. Forages. The Science of Grassland Agriculture. Volume II. 6th Edition. Blackwell Publishing. USA.

Budiman. 2012. Studi perkembangan morfologi pada fase vegetatif dan reproduktif tiga kultivar rumput gajah (Pennisetum purpureum Schum). Disertasi. Program Pascasarjana Fakultas Peternakan Universitas Gadjah Mada. Yogyakarta.

Budiman, R. D. Soetrisno, S. P. S. Budhi and A. Indrianto. 2012. Total Non Structural Carbohydrate (TNC) of three cultivar of napier Grass (Pennisetum purpureum Schum) at vegetatif and generatif phase. J. Indonesian Trop. Anim. Agric. 36(2):126 - 130.

Dimu Heo, Y. H. 2012. Pertumbuhan dan hasil kacang tanah varietas lokal asal Nusa Tenggara Timur pada tanah salin dengan pemberian bahan organik. Tesis. Program Pascasarjana Fakultas Pertanian Universitas Gadjah Mada. Yogyakarta.

Ferguson, B. J., A. Indrasamunar, S. Hayashi, M. Lin, Y. Lin, D. E. Reid and P. M. Gresshoff. 2010. Molecular analysis of legume nodule development and autoregulation. Journal of Integrative Plant Biology. 52(1):61-76.

Fuskhah, E. 2011. Pemanfaatan bakteri rhizobium tahan salin dan kalsium untuk pengembangan tanaman leguminosa pakan di lahan pantai utara Jawa Tengah. Disertasi. Program Pascasarjana Fakultas Peternakan Universitas Gadjah Mada. Yogyakarta.

Fuskhah, E., S. Anwar, E.D. Purbajanti, R. D. Soetrisno, S.P.S. Budhi and A. Maas. 2007. Eksplorasi dan seleksi ketahanan rhizobium terhadap salinitas dan kemampuan berasosiasi dengan leguminosa pakan J. Indonesian Trop. Anim. Agric. 32 (3):179-185.

Ginting, S. P and A. Tarigan. 2005. Kualitas nutrisi beberapa legum herba pada kambing: konsumsi, kecernaan dan neraca nitrogen. Jurnal Ilmu Ternak dan Veteriner. 10(4):268 274

Gomez, K. A. and A. A. Gomez. 1984. Statistical Procedures for Agricultural Research. John Wiley \& Sons, Inc.

Heldt, H. W., and B. Piechulla. 2011. Plant Biochemistry . $4^{\text {th }}$ Ed. Academic Press. USA.

Hutasoit R. 2010. Pengaruh pemberian rock posphate dan pupuk hayati terhadap produksi dan kualitas Stylosanthes guianensis CIAT 184. Tesis. Program Pascasarjana Fakultas Peternakan Universitas Gadjah Mada. Yogyakarta. 
Koten, B. B., R. D. Soetrisno and B. Suhartanto. 2005. Pengaruh umur panen dan penambahan inokulum terhadap produktivitas hijauan kacang tunggak (Vigna unguiculata) sebagai pakan. Jurnal Agrosains. 18(1):43-53.

Laboratorium Hijauan Makanan Ternak dan Pastura. 2010. Hasil analisa proksimat hijauan arbila (Phaseolus lunatus). Fakultas Peternakan Universitas Gadjah Mada. Yogyakarta.

Lukiwati, D.W. 2007. Peningkatan produksi dan kecernaan bahan kering Centrosema pubescens dan Pueraria phaseoloides oleh pemupukan batuan fosfat dan inokulasi MVA. Jurnal Ilmu-ilmu Pertanian Indonesia. 9(1):15.

Parman, S. 2007, Kandungan protein kasar dan abu tanaman alfalfa (Medicago sativa L.) setelah pemupukan biorisa. Jurnal Bioma. 9(2):38-44.

Pudjiati. 2004. Produksi bahan kering, serapan N dan P hijauan pada pertanaman ganda setaria dan puero atau centro dengan pemupukan fosfat dari sumber yang berbeda. Tesis. Program Pascasarjana Fakultas Peternakan Universitas Diponogoro Semarang.

Purwaningsih, Ch. S. 2011. Pengaruh pemberian kompos blotong, legin, dan mikoriza terhadap serapan hara $\mathrm{N}$ dan $\mathrm{P}$ tanaman kacang tanah. Widya Warta. 2 (35):55-68.

Sirait, J., A. Tarigan, dan K. Simanhuruk. 2011. Pemanfaatan alfalfa yang ditanam di dataran tinggi tobasa, Provinsi Sumatra Utara untuk pakan kambing boerka sedang tumbuh. Jurnal Ilmu Ternak dan Veteriner. 16 (4): 294 - 303.

Widawati, S. 2010. Introduksi inokulan mikrobia tanah sebagai pemacu pertumbuhan tanaman legum pada tanah marginal. Berkala Penelitian Hayati. Edisi Khusus. 4F: 37 - 42.

Widyati-Slamet, F. Kusmiyati, Endang Purbajanti dan Surahmanto. 2009. Produksi dan kualitas hijauan alfalfa (Medicago sativa) pemotongan pertama pada media tanam yang berbeda dan penggunaan inokulan. Makalah Seminar Nasional Kebangkitan Peternakan, Semarang, 20 Mei 2009: 295 - 301 